Jurnal Akuntansi \& Perpajakan, Volume 1, No. 2, Januari 2020

\title{
PENGARUH KOMPETENSI DAN INDEPENDENSI TERHADAP KUALITAS AUDIT PADA KANTOR AKUNTAN PUBLIK DI WILAYAH JAKARTA
}

\author{
Riyanto Wujarso', Saprudin ${ }^{2}$ \\ Sekolah Tinggi Ilmu Ekonomi Jayakarta \\ riyanto.rw@gmail.com $^{1}$, saprudinmaksudi@gmail.com ${ }^{2}$
}

\begin{abstract}
ABSTRAK
Penelitian menguji apakah kompetensi dan independensi berpengaruh terhadap kualitas audit. auditor harus memiliki kompetensi yang cukup, mampu mempertahankan independensi dalam mengaudit laporan keuangan suatu entitas untuk meningkatkan kepercayaan masyarakat. Sampel dalam penelitian ini adalah auditor yang bekerja di Kantor Akuntan Publik (KAP) yang berada di Jakarta dengan jumlah 83 responden dan perusahaan pengguna jasa audit Kantor Akuntan Publik dengan jumlah 17 responden, sehingga total sampel yang digunakan berjumlah 100 responden. Adapun metode pengambilan sampel yang diambil adalah purposive sampling. Kuesioner adalah alat yang digunakan untuk mengukur variabel. Teknik analisis dalam penelitian ini menggunakan analisis regresi linear berganda.Hasil pengujian hipotesis menunjukan bahwa kompetensi berpengaruh signifikan terhadap kualitas audit, dan independensi tidak berpengaruh terhadap kualitas audit. Namun berdasarkan analisis secara simultan menunjukan bahwa kompetensi dan independensi secara simultan (bersama-sama) berpengaruh signifikan terhadap kualitas audit.
\end{abstract}

Kata kunci: Kompetensi, Independensi, Kualitas Audit.

I. PENDAHULUAN.

Laporan keuangan membuka akses entitas ke pendanaan, aspek perpajakan, hingga kepercayaan eksternal. Bayangkan jika laporan itu dibuat secara tidak bertanggungjawab. Seorang pejabat publik pernah dibuat terheran-heran ketika membaca ratusan laporan audit yang masuk ke mejanya. Sekilas laporan itu terkesan wajar. Namun ada lebih dari seratus laporan audit yang ditanda-tangani oleh satu KAP yang sama dalam waktu hampir bersamaan. Bukan oleh KAP sekelas "big four" yang memiliki partner puluhan orang, tapi oleh KAP kecil dengan jumlah partner tidak lebih dari dua. Yang lebih membuat heran, semuanya mendapat opini Wajar Tanpa Pengecualian alias WTP. Bagaimana mungkin dalam waktu hanya sekitar dua pekan, sebuah KAP bisa memeriksa lebih dari seratus klien, dan semuanya selesai tepat waktu.

Di tengah iklim serba transparan, ternyata praktik-praktik seperti itu masih marak terjadi. Banyak dugaan miring sejumlah akuntan publik (AP) memberikan opini tanpa adanya pemeriksaan. Sehingga muncul plesetan dari WTP adalah Wajar Tanpa Pemeriksaan. Di kasus lain pun, masih ada AP yang membubuhkan 
Jurnal Akuntansi \& Perpajakan, Volume 1, No. 2, Januari 2020

tanda tangan di laporan audit tapi justru tak punya kertas kerja. IAPI sendiri hanya bisa melakukan sanksi dari aspek keanggotaan. Regulator dalam hal ini adalah Pusat Pembinaan Profesi Keuangan (P2PK) Kementerian Keuangan dulu Pusat Pembinaan Akuntan dan Jasa Penilai (PPAJP). kilah Ketua Institut Akuntan Publik Indonesia (IAPI). (Tarko Sunaryo, 2015)

Menurut Ikatan Akuntan Indonesia (2015), laporan keuangan yang berguna bagi pemakai informasi bahwa harus terdapat empat karakteristik kualitatif pokok yaitu dapat dipahami, relevan, keandalan, dan dapat diperbandingkan. Keempat karakteristik tersebut sangatlah sulit untuk diukur, sehingga para pemakai informasi membutuhkan jasa pihak ketiga yaitu auditor independen. Audit sebagai proses pengumpulan dan evaluasi bukti tentang informasi untuk menentukan dan melaporkan derajat kesesuaian antara informasi itu dengan yang telah ditetapkan (Arens, 2014). Pemberian audit dan jasa terkait lain harus bermutu, sangat penting karena untuk melindungi kepentingan publik, kepuasan kepada klien, kepatuhan terhadap standar profesi dan reputasi profesional.

Beberapa permasalahan yang perlu menjadi perhatian para akuntan diantaranya diberhentikannya perdagangan suatu emitan oleh BEI karena banyak ditemukan kesalahan dalam laporan keuangan, dikenakannya sanksi salah satu mitra Ernst \& Young di Indonesia oleh PCAOB, bahkan dugaan keterlibatan akuntan publik dalam menyusun laporan keuangan suatu perusahaan yang digunakan untuk mengajukan kredit ke bank.

Penelitian ini dilakukan terhadap 31 Kantor Akuntan Publik dan 16 perusahaan pengguna jasa audit di Jakarta. Tujuan penelitian ini untuk mengetahui seberapa besar pengaruh kompetensi, independensi, profesionalitas dan motivasi terhadap kualitas audit. Penelitian ini dapat bermanfaat bagi KAP (Kantor Akuntan Publik) dan Auditor maupun pihak-pihak pemakai laporan keuangan audited, agar dapat mengetahui faktor-faktor yang mempengaruhi kualitas audit sehingga dapat meningkatkan kualitas audit tersebut, dan dapat menambah pengetahuan dan wawasan terkait pemahaman Kompetensi dan Independensi terhadap Kualitas Audit pada Kantor Akuntan Publik.

\section{LITERATUR DAN METODE}

Pada perusahaan yang berbentuk perseroan, biasanya telah dilakukan pemisahan antara pemilik perusahaan dan manajer perusahaan. Pemilik atau pemegang saham adalah pihak yang menyertakan modal ke dalam perusahaan, sedangkan manajer adalah pihak yang ditunjuk pemilik dan diberi kewenangan mengambil keutusan dalam mengelola perusahaan, dengan harapan manajemen bertindak sesuai dengan kepentingan pemilik. Karena adanya pemisahan antara pemilik dan pihak pengelola (manajemen), kemungkinan adanya perbedaan kepentingan di antara kedua pihak tidak bisa dihindari. Pihak manajemen dapat bertindak untuk kepentingannya sendiri dalam 
Jurnal Akuntansi \& Perpajakan, Volume 1, No. 2, Januari 2020

mengelola perusahaan dan mengabaikan kepentingan pemilik perusahaan (Sudana, 2011).

Teori agensi adalah studi tentang bagaimana para pemegang saham dapat memotivasi manajemen untuk menerima model SWM (Shareholder Wealth Maximization) atau maksimisasi kekayaan pemegang saham. Secara spesifik, perusahaan harus berusaha keras memaksimalkan pengembalian pemegang saham, sebagaimana diukur dengan jumlah keuntungan modal dan deviden, berdasarkan tingkat resiko tertentu. Selain itu, perusahaan juga harus meminimalkan resiko bagi para pemegang saham untuk tingkat pengembalian tertentu (Eiteman, 2013).

Walaupun tujuan perusahaan adalah memaksimalkan kekayaan para pemegang saham, kenyataannya, masalah keagenan dapat terjadi pada saat tujuan diimplementasikan. Agen adalah orang yang diberi kekuasaan untuk bertindak atas nama yang lain, dikenal sebagai prinsipal. Dalam mengatur perusahaan, pemegang saham adalah prinsipal, sebab mereka adalah pemilik nyata dari perusahaan. Dewan direksi, CEO, para eksekutif perusahaan dan semuanya dengan kekuasaan pengambilan keputusan adalah agen (perantara) dari pemegang saham. Sayangnya, mereka tidak selalu melakukan apa yang menjadi kepentingan terbaik bagi pemegang saham, sebagai gantinya mereka sering kali bertindak untuk kepentingan mereka sendiri (keown, 2017).

Menurut Arens (2014) auditing adalah pengumpulan dan evaluasi bukti tentang informasi untuk menentukan dan melaporkan derajat kesesuaian antara informasi itu dengan yang telah ditetapkan. Adapun menurut Sukrisno (2012) auditing adalah "Suatu pemeriksaan yang dilakukan secara kritis dan sistematis, oleh pihak independen, terhadap laporan keuangan yang telah disusun oleh manajemen, beserta catatan - catatan pembukuan dan bukti-bukti pendukungnya, dengan tujuan untuk dapat memberikan pendapat mengenai kewajaran laporan keuangan tersebut".

Menurut IAPI (2011)

terdapat empat jenis audit yaitu:

1. Management Audit (Operasional Audit)

2. Complience Audit (PemeriksaanKetaatan)

3. Intern Audit (Pemeriksaan Intern)

4. Computer Audit (Komputerisasi Audit)

Ada lima prinsip dalam Bagian A kode etik profesional yang telah ditetapkan dan disahkan oleh Institut Akuntansi Publik Indonesia dalam Pernyataan Standar Auditing [8], kelima prinsip yang harus diterapkan auditor adalah sebagai berikut:

1) Prinsip Integritas

2) Prinsip Objektifitas

3) Prinsip Kompetensi serta Sikap Kecermatan dan Kehati-hatian

4) Prinsip Kerahasiaan

5) Prinsip Perilaku Profesional

Menurut Standar Akuntansi Keuangan (SAK) Laporan keuangan merupakan bagian dari proses pelaporan keuangan. Laporan keuangan yang lengkap biasanya meliputi neraca, laporan laba rugi, laporan perubahan posisi 
Jurnal Akuntansi \& Perpajakan, Volume 1, No. 2, Januari 2020

keuangan (yang dapat disajikan dalam berbagai cara seperti, misalnya; sebagai laporan arus kas, atau laporan arus dana), catatan dan laporan lain serta materi penjelasan yang merupakan bagian integral dari laporan keuangan. Di samping itu juga ternasuk skedul dan informasi tambahan yang berkaitan dengan laporan tersebut, misal : informasi keuangan segmen industri dan geografis serta pengungkapan pengaruh perubahan harga (IAI, 2015).

Menurut Arens (2014) kompetensi adalah "Auditor harusmemiliki kualifikasi untuk memahami kriteria yang digunakan dan haruskompeten untuk mengetahui jenis serta jumlah bukti yang akandikumpulkan guna mencapai kesimpulan yang tepat setelah memeriksabukti itu".

Standar Profesional Akuntan Publik standar umum pertama berbunyi bahwa audit harus dilaksanakan oleh orang yang memiliki keahlian dan pelatihan teknis cukup sebagai auditor (IAPI, 2011).

Adapun menurut Mulyadi (2013) kompetensi diperoleh melalui pendidikan dan pelatihan. Sedangkan menurut Wibowo (2016) kompetensi adalah suatu kemampuan untuk melaksanakan atau melakukan suatu pekerjaan atau tugas yang dilandasi atas keterampilan dan pengetahuan serta didukung oleh sikap kerja yang dituntut oleh pekerjaan tersebut.

Dengan demikian dapat disimpulkan, bahwa kompetensi auditor adalah kepemilikan atas aspek-aspek pribadi disertai pengetahuan, keahlian, dan pengalaman yang mengarah kepada tingkah laku sehingga menghasilkan kinerja yang baik, untuk melakukan audit secara objektif, cermat, dan seksama.

Independensi menurut Arens (2014) berarti mengambil sudut pandang yang tidak bias. Auditor tidak hanya harus independen dalam fakta, tetapi juga harus independen dalam penampilan. Terdapat dua aspek independensi yang dimiliki oleh auditor, yaitu independensi dalam fakta dan independensi dalam penampilan [3]

Menurut Mulyadi (2013) sikap mental independen auditor harus meliputi independen dalam fakta, maupun independen dalam penampilan. Adapun menurut Kumaat (2011), bahwa independensi dalam auditor internal dibagi menjadi tiga yaitu independensi dalam program audit, independensi dalam verifikasi, dan independensi dalam pelaporan.

Menurut Tuanakotta (2014) pemberian audit dan jasa terkait lain harus bermutu, sangat penting karena untuk melindungi kepentingan publik, kepuasan kepada klien, kepatuhan terhadap standar profesi dan reputasi profesional.

Adapun menurut Porter (2003) berdasarkan konsep auditing, kualitas audit berhubungan dengan independensi, kompetensi dan kode etik auditor. Independensi dan kompetensi menjadi faktor penting yang harus dimiliki seorang auditor dalamrangka pelaksanaan tugas audit.

Ikatan Akuntan Indonesia (IAI) menyatakan bahwa audit yang dilakukan auditor dikatakan berkualitas, jika memenuhi standar 
Jurnal Akuntansi \& Perpajakan, Volume 1, No. 2, Januari 2020

auditing dan standar pengendalian mutu. Dalam Buku Yusar Sagara (2013) standar auditing adalah sepuluh standar yang ditetapkan dan disahkan oleh Institut Akuntan Publik Indonesia (IAPI), yang terdiri dari standar umum, standar pekerjaan dan standar pelaporan.

Ada beberapa faktor yang mempengaruhi kualitas audit menurut Karismatuti (2012) diantaranya: Tenure, Jumlah klien, Kesehatan keuangan klien, dan adanya pihak ketiga yang akan melakukan review atas laporan audit.

Dalam penelitian Aprilia Whetyningtyas (2014) tentang pengaruh kompetensi, independensi, dan profesionalitas auditor terhadap kualitas audit, yang dilakukan pada KAP di Semarang menyatakan bahwa kompetensi tidak berpengaruh terhadap kualitas audit. Sementara dalam penelitian Mochamad Ichrom (2015) tentang pengaruh kompetensi, independensi dan motivasi terhadap kualitas audit yang dilakukan pada KAP di Surabaya menyatakan bahwa kompetensi berpengaruh positif terhadap kualitas audit. Faktor pengalaman, pengetahuan yang rendah, belum mampu melakukan analisis yang rinci dan mendalam, membuat kegagalan dalam mendeteksi kekeliruan. Kompetensi dan kehati-hatian profesional merupakan bagian dari prinsip etika dalam kode etik profesi akuntan publik.

(2014) tentang pengaruh kompetensi, independensi dan motivasi terhadap kualitas audit, menyatakan bahwa independensi auditor berpengaruh positif terhadap kualitas audit. Sedangkan dalam penelitian Mochamad Ichrom (2015) tentang pengaruh kompetensi, independensi dan motivasi terhadap kualitas audit yang dilakukan pada KAP di Surabaya menyatakan bahwa independensi berpengaruh negatif terhadap kualitas audit. Hal ini mengindikasikan bahwa auditor tidak selalu dapat menjaga independensi yang dimilikinya, sehingga menurunkan audit yang dihasilkan. Independensi, Integritas, Obyektivitas merupakan bagian dari aturan etika dalam kode etik profesi akuntan publik.

Pada penelitian Martin (2013) tentang "Audit Quality Indicators: Audit Practice Meets Audit Research" menjelaskan bahwa nilai indikator kualitas audit dari perspektif berbagai pemangku kepentingan ada pada proses pelaporan keuangan. Praktisi telah bekerja umtuk memahami dan mengelola pendorong utama kualitas uadit, seperti bagaimana proses kontrol kualitas audit, sedangkan akademisi akan membawa objektivitas dan kekakuan pada mereka untuk tantangan. Sedangkan pada penelitian David N. Herda (2016) yang berjudul "The Effects of Auditor Experience and Professional Commitment on Acceptence of Underreporting Time: A Moderated Mediation Analysis" menjelaskan bahwa perusahaan audit harus secara efektif melatih staff untuk memahami konsekuensi yang merugikan atas tidak dilaporkannya waktu yang digunakan. Pendidikan lebih lanjut, kualifikasi akuntansi profesional, budaya organisasi dan 
Jurnal Akuntansi \& Perpajakan, Volume 1, No. 2, Januari 2020

keanggotaan profesional cenderung mempengaruhi komitmen profesional antar auditor.

Kerangka berfikir merupakan model konseptual tentang bagaimana teori berhubungan dengan berbagai faktor yang telah diidentifikasi sebagai masalah yang penting. Kerangka berfikir yang baik akan menjelaskan secara teoritis pertautan antar variabel yang akan diteliti. Jadi secara teoritis perlu dijelaskan hubungan antar variabel independen dan dependen. Pertautan antar variabel tersebut, selanjutnya dirumuskan ke dalam bentuk paradigma penelitian. Oleh karena itu pada setiap penyusunan paradigma penelitian harus didasarkan pada kerangka berfikir (Sugiyono, 2013). Dalam penelitian ini yang di maksud variabel independen terdiri dari variabel Kompetensi (X1), Independensi (X2). Sedangkan variabel dependen yaitu Kualitas Audit (Y). Berkualitas atau tidaknya suatu audit dapat dipengaruhi oleh kompetensi dan independensi yang diterapkan auditor dalam menjalankan pekerjaannya.

Hipotesis adalah jawaban yang bersifat sementara terhadap permasalahan penelitian sampai terbukti melalui data yang terkumpul (Arikunto, 2010). Berdasarkan landasan teori dan kerangka pemikiran diatas, maka hipotesis atau dugaan sementara yang dilakukan adalah dapat dirumuskan :

$\mathrm{H} 1$ = Terdapat pengaruh antara Kompetensi Terhadap Kualitas Audit.
$\mathrm{H} 2$ = Terdapat pengaruh antara Independensi Terhadap Kualitas Audit.

H3= Terdapat pengaruh antara Kompetensi dan Independensi Terhadap Kualitas Audit

\section{METODE}

Menurut Sugiyono (2013), variabel penelitian pada dasarnya adalah segala sesuatu yang berbentuk apa saja yang ditetapkan oleh peneliti untuk dipelajari sehingga diperoleh informasi tentang hal terebut, kemudian di tarik kesimpulannya.

Adapun objek pengamatan yang di peroleh dalam penelitian ini adalah sebagai berikut :

1. Kompetensi (X1)

2. Independensi (X2)

3. Kualitas Audit (Y)

Subjek penelitian merupakan tempat variabel melekat yaitu pada auditor kantor akuntan publik (KAP) dan perusahaan pengguna jasa audit dengan kriteria sebagai berikut:

1. KAP yang terdaftar pada Pusat Pembinaan Profesi Keuangan (PPPK) Kementerian Keuangan RI dan direktori akuntan publik Indonesia (IAPI)

2. KAP dan perusahaan yang bersedia menerima kuesioner.

3. Audior yang bekerja pada KAP yang berada di wilayah Jakarta.

4. Jabatan yang dapat diklasifikasikan adalah pimpinan partner, partner, manajer, dan supervisor auditor.

Desain yang akan dilakukan dalam penelitian ini adalah jenis penelitian deskriptif - kausalitas. Dimana pengertian dari desain penelitian deskriptif menurut 
Jurnal Akuntansi \& Perpajakan, Volume 1, No. 2, Januari 2020

Arikunto (2010) adalah desain penelitian yang disusun dalam rangka memberikan gambaran sistematis tentang informasi ilmiah yang berasal dari subjek dan objek penelitian. Menurut Anwar Sanusi (2017), desain penelitian kausalitas adalah desain penelitian yang disusun untuk meneliti kemungkinan adanya hubungan sebab-akibat antara variabel. Jenis data yang digunakan berupa data subjek dan wujudnya tertulis, data tersebut diperoleh dari informasi hasil penyebaran kuesioner yang diberikan kepada responden.

Populasi adalah seluruh kumpulan elemen yang menunjukkan ciri - ciri tertentu yang dapat digunakan untuk membuat kesimpulan. Jadi, kumpulan elemen itu menunjukkan jumlah, sedangkan ciri - ciri tertentu menunjukkan karakteristrik dari kumpulan itu (Sanusi, 2017). Oleh karena itu populasi yang digunakan dalam penelitian ini merupakan seluruh auditor yang bekerja pada beberapa Kantor AkuntanPublik yang berada di Jakarta yang terdaftar dalam Pusat Pembinaan Profesi Keuangan (PPPK) Kementerian Keuangan RI per 31 Desember 2017 yang berjumlah 227 KAP dan klien atau perusahaan pengguna jasa audit KAP tersebut.

Menurut Sugiyono (2013) sampel adalah bagian dari jumlah dan karakteristik yang dimiliki populasi tersebut. Sampel yang dipilih dari populasi dianggap mewakili keberadaan populasi. Adapun teknik penarikan sampel menggunakan metode purposive sampling yaitu teknik penarikan sampel dari semua anggota populasi berdasarkan atas kriteria-kriteria tertentu yang diterapkan berdasarkan tujuan penelitian. Besarnya sampel dalam penelitian ini berjumlah 100 responden dari 31 KAP yang berada di wilayah Jakarta dan 16 perusahaan pengguna jasa audit dari KAP tersebut.

Dalam penelitian ini, pengumpulan data dilakukan menggunakan cara survei, dimana peneliti atau pengumpul data mengajukan pertanyaan atau pernyataan kepada responden secara tertulis yang disebut dengan data kuesioner.

$\begin{array}{lr}\text { Mengingat } & \text { pengumpulan } \\ \text { data dilakukan } & \begin{array}{r}\text { menggunakan } \\ \text { kesungguhan }\end{array} \\ \text { kuesioner, maka } & \text { menjawab } \\ \text { responden dalam } & \text { menjan } \\ \text { pertanyaan-pertanyaan merupakan }\end{array}$
hal sangat penting dalam penelitian keabsahan dan kesahihan suatu penelitian sosial sangat ditentukan oleh alat ukur yang digunakan. Dalam mengatasi hal tersebut diperlukan dua macam pengujian, yaitu uji validitas (test of validity) dan uji keandalan (test of reliability) untuk menguji kesungguhan jawaban responden.

Uji validitas digunakan untuk mengukur sah atau valid tidaknya suatu kuesioner. Suatu kuesioner dikatakan valid jika pertanyaan pada kuesionertersebut mampu untuk mengungkapkan sesuatu yang diukur oleh kuesioner tersebut (Ghozali, 2011). Uji reliabilitas dimaksudkan untuk menguji konsistensi kuesioner dalam mengukur suatu kontrak yang sama atau stabilitas kuisioner jika digunakan dari waktu ke waktu. Reliabilitas instrument penelitian dalam penelitian ini diuji dengan 
Jurnal Akuntansi \& Perpajakan, Volume 1, No. 2, Januari 2020

menggunakan koefisien cronbach's Alpha.

Uji Normalitas digunakan untuk melakukan pengujian apakah dalam model regresi, variabel pengganggu atau residual memiliki distribusi normal. Dalam Uji Normalitas terdapat dua cara untuk mendeteksi apakah residual berdistribusi normal atau tidak yaitu dengan analisis grafik dan uji statistik (Ghozali, 2011).

Uji Multikolineritas bertujuan untuk menguji apakah model regresi ditemukan adanya kolerasi antar variabel bebas (independen). Model regresi yang baik seharusnya tidak terjadi korelasi diantara variabel independen. Jika variabel independen berkorelasi maka variabel variabel ini tidak ortogonal [24]. Nilai cutoff yang umum dipakaiuntuk menunjukkan adanya multikoloniaritas adalah nilai Tolerance $<0,10$ atau sama dengan nilai VIF $>10$.

Uji Heteroskedastisitas bertujuan menguji apakah dalam modelregresi terjadi ketidaksamaan variance dari residual satu pengamatan kepengamatan lainnya. Jika varian dari residual satu pengamatan kepengamatan lain tetap, maka disebut Heteroskedastisitas. Model regresiyang baik adalah heteroskedastisitas atau tidak terjadi heteroskedastisitas (Ghozali, 2011). Keeratan hubungan dinyatakan dalam bentuk koefisien korelasi, yaitu nilai yang digunakan untuk mengukur kekuatan (keeratan) suatu hubungan antar variabel. Nilai koefisien korelasi antara -1 hingga +1 . Sifat nilai koefisien korelasi adalah positif (+) atau negatif (-). Hal ini menunjukan arah korelasi. Dalam uji korelasi sifat dari korelasi tersebut akan menentukan arah dari korelasi. Signifikansi hubungan antara variabel yang diteliti dapat dianalisis dengan ketentuan sebagai berikut :

1. Jika probabilitas atau signifikansi $<0,05$ hubungan antar variabel signifikan.

2. Jika probabilitas atau signifikansi > 0,05 hubungan antar variabel tidak signifikan.

Regresi bertujuan untuk menguji pengaruh satu variabel terhadap variabel lain. Variabel yang dipengaruhi disebut variabel terikat sedang variabel yang mempengaruhi disebut variabel bebas (Ghozali, 2011). Penelitian ini menggunakan analisa regresi ganda karena memiliki variable dependent lebih dari satu.

Metode analisis yang digunakan untuk menjawab hipotesis yang telah dibuat adalah sebagai berikut :

1. Uji Koefisien Determinasi (R2)

2. Uji Signifikan Simultan (Uji Statistik F)

3. Uji Signifikan Parameter Individual (Uji Statistik t)

Adapun tools yang akan digunakan dalam penelitian ini adalah dengan menggunakan SPSS 22.

\section{HASIL DAN PEMBAHASAN}

Dalam uji regresi, diperoleh data sebagai berikut:

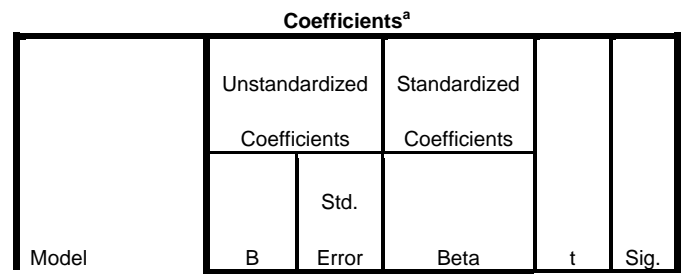


Jurnal Akuntansi \& Perpajakan, Volume 1, No. 2, Januari 2020

\begin{tabular}{|r|r|r|r|r|r|}
\hline 1 (Constant) & 14.697 & 3.504 & & 4.194 & .000 \\
Kompetensi & .408 & .101 & .436 & 4.026 & .000 \\
\hline \multicolumn{1}{|c|}{ Independensi } & .161 & .096 & .181 & 1.677 & .097 \\
\hline
\end{tabular}

a. Dependent Variable: KualitasAudit

\section{Kompetensi Berpengaruh Terhadap Kualitas Audit (X1 - Y)}

Hasil pengujian didapat $p$ value $=0,000<0,05$ dan nilai thitung $>$ $t_{\text {tabel }}(4,026>1,664)$, sehingga dapat dikatakan bahwa kompetensi $\left(\mathrm{X}_{1}\right)$ berpengaruh signifikan terhadap kualitas audit (Y) pada kantor akuntan publik.

Seorang auditor harus memiliki kompetensi yang cukup. Meskipun dekimian, tingginya kompetensi yang dimiliki oleh auditor tidak dapat menjamin terbebasnya salah saji laporan audit. Hal ini terbukti dengan adanya fenomena seperti adanya sanksi yang diberikan oleh PCAOB kepada partner KAP Purwantono, Suherman \& Surya (Mitra E\&Y Indonesia) yaitu Roy Iman Wirahardja sebagai akibat dari ditemukannya kesalahan dalam laporan audit PT. Indosat, Tbk dalam hal kurangnya bukti pendukung atas transaksi sewa 4.000 menara seluler, namun akuntan mengeluarkan opini Wajar Tanpa Pengecualian (Modesti, 2017). Sanksi yang diberikan kepada mitra E\&Y tersebut berupa denda USD 20.000 dan larangan berprakrik selama 5 tahun.

Fenomena lain yang meragukan perihal kompetensi auditor adalah kesalahan penyajian laporan audit PT. Inovasi Infracom Tbk. oleh KAP Djamaludin, Ardi, Sukimto \& Rekan dalam akun biaya gaji yang disajikan sebesar 1,91 Triliun namun setelah dikonfirmasi ulang perusahaan menyatakan bahwa biaya gaji seharusnya 1,9 Milyar. Kesalahan lain adalah tidak sesuainya saldo aset tetap awal 2014 dengan saldo akhir aset tetap tahun 2013 dan ditemukannya Overstated bagian laba bersih perusahan (Riandhini, 2015). Akibat dari ditemukannya berbagai kesalahan dalam laporan keuangan tersebut membuat dihentikannya perdagangan saham emiten oleh PT. BEI. Dengan ditemukannya kesalahan-kesalahan dalam penyajian laporan audit tersebut maka dapat dikatakan bahwa auditor tidak kompeten sehingga kualitas audit menjadi semakin rendah.

Penelitian ini bertentangan dengan hasil penelitian [16] tentang pengaruh kompetensi, independensi, dan profesionalitas auditor terhadap kualitas audit, yang dilakukan pada KAP di Semarang menyatakan bahwa kompetensi tidak berpengaruh terhadap kualitas audit. Namun hasil penelitian ini sesuai dengan penelitian Mochamad Ichrom (2015) tentang pengaruh kompetensi, independensi dan motivasi terhadap kualitas audit yang dilakukan pada KAP di Surabaya, yang menyatakan bahwa kompetensi berpengaruh positif terhadap kualitas audit.

\section{Independensi Berpengaruh Terhadap Kualitas Audit ( $\left.\mathbf{X}_{2}-\mathbf{Y}\right)$ Hasil pengujian didapat $p$ - value $=0,097>0,05$ dan nilai $t_{\text {hitung }}>$ $t_{\text {tabel }}(1,677<1,664)$, sehingga dapat tafsirkan bahwa independensi $\left(\mathrm{X}_{2}\right)$ tidak berpengaruh signifikan terhadap kualitas audit (Y) pada}


Jurnal Akuntansi \& Perpajakan, Volume 1, No. 2, Januari 2020

kantor akuntan publik pada tingkat signifikansi $5 \%$.

Independensi tidak

berpengaruh terhadap kualitas audit, salah satu indikasinya sesuai dengan hasil wawancara peneliti dengan salah satu Manajer Audit KAP di Jakarta, bahwa kantornya selain melakukan jasa audit juga menerima jasa penyusunan laporan keuangan, bahkan ada beberapa klien auditnya yang penyusunan laporan keuangannya dilakukan oleh tim divisi accounting service kantornya. Beliau menjelaskan bahwa kliennya selain sebagai klien audit mereka juga sebagai klien accounting service. Hal ini menurut beliau, tentu dapat menyalahi prinsip independensi auditor, karena dua jasa yang diberikannya yang harus dilakukan oleh pihak yang berbeda namun dilakukan oleh pihak yang sama.

Penelitian ini sejalan dengan hasil penelitian Putu Septiani Futri (2014) tentang pengaruh independensi, profesionalisme, tingkat pendidikan, etika profesi, pengalaman, dan keupasan kerja auditor pada kualitas audit kantor akuntan publik di Bali. Yang menyatakan bahwa independensi tidak pengaruh terhadap kualitas audit. penelitian Mochamad IChrom (2015) tentang pengaruh kompetensi, independensi dan motivasi terhadap kualitas audit yang dilakukan pada KAP di Surabaya, juga menyatakan bahwa independensi berpengaruh negatif terhadap kualitas audit. Hal ini mengindikasikan bahwa auditor tidak selalu dapat menjaga independensi yang dimilikinya, sehingga menurunkan kualitas audit yang dihasilkan.
Namun hasil penelitian ini tidak sejalan dengan penelitian $\mathrm{Ni}$ Wayan (2014) tentang pengaruh kompetensi, independensi dan motivasi terhadap kualitas audit, menyatakan bahwa independensi auditor berpengaruh positif terhadap kualitas audit.

Kompetensi dan Independensi Berpengaruh Terhadap Kualitas Audit $\left(\mathbf{X}_{1}, \mathbf{X}_{2},-\mathbf{Y}\right)$

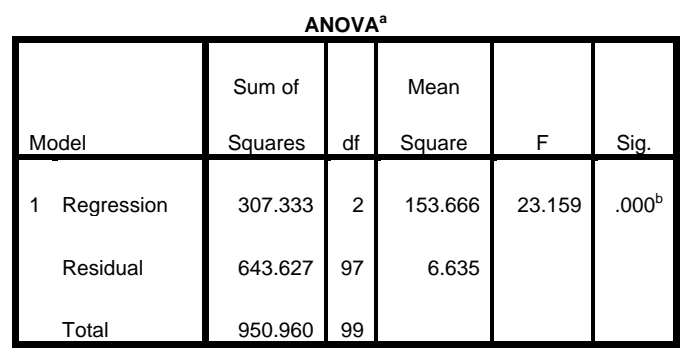

a. Dependent Variable: KualitasAudit

b. Predictors: (Constant), Independensi, Kompetens

Hasil pengujian diperoleh $F_{\text {hitung }}$ sebesar 23,159 dan nilai Sig. $(P$-Value $)$ sebesar 0,000. Karena $\mathrm{F}_{\text {hitung }}=23,159>\quad \mathrm{t}_{\text {tabel }}=2,460$ sehingga kompetensi $\left(\mathrm{X}_{1}\right)$ dan independensi $\left(\mathrm{X}_{2}\right)$ secara simultan berpengaruh terhadap kualitas audit (Y) dan karena Sig. $(P$-Value $)=$ $0,000<\alpha=0,05$ maka pengaruh simultan tersebut secara signifikan.

Hasil penelitian ini menunjukan bahwa secara simultan kompetensi dan independensi berpengaruh terhadap kualitas audit. kompetensi auditor yang diperoleh dari tingkat pendidikan dan pengamalan kerja yang dimiliki akan menjadikan auditor dapat bekerja dengan baik, sehingga kualitas audit audit yang dihasilkan akan meningkat. Sedangkan independensi auditor dengan yang tercermin dalam sikap independen dalam program, dalam memferifikasi data dan dalam 
Jurnal Akuntansi \& Perpajakan, Volume 1, No. 2, Januari 2020

membuat laporan audit akan meningkatkan kualitas auditnya.

\section{KESIMPULAN}

Berdasarkan hasil penelitian yang telah dilakukan untuk menganalisis pengaruh kompetensi dan independensi terhadap kualitas audit pada kantor akuntan publik dan perusahaan pengguna jasa audit di Jakarta, dapat disimpulkan antara lain :

1. Kompetensi berpengaruh signifikan terhadap kualitas audit, hal ini menunjukan bahwa seorang auditor harus memiliki kompetensi yang memadai dalam melaksanakan pekerjaannya.

2. Independensi tidak berpengaruh signifikan terhadap kualitas audit, hal ini terjadi karena adanya akuntan publik yang mengerjakan dua jenis pekerjaan yang seharusnya tidak dapat dikerjakan bersamaan, yaitu antara jasa general audit dengan jasa penyusunan laporan keuangan untuk satu entitas.

3. Kompetensi dan independensi secara bersama-sama berpengaruh terhadap kualitas audit. kemampuan yang dimiliki auditor, berpegang teguh pada prinsip atau mampu mempertahankan independensi, akan membuat kualitas audit yang dihasilkan oleh akuntan publik menjadi baik.

Para akuntan publik juga harus selalu menjaga dan menjunjung tinggi etika profesinya, demi nama baik profesi akuntan publik itu sendiri. Jika laporan audit yang disajikan auditor mencerminkan apa adanya, maka akan tidak ada pihak yang merasa dirugikan dan hal ini juga akan membuat iklim bisnis menjadi lebih baik. Sehingga tidak ada pihak investor atau kreditor yang dirugikan. Bagi peneliti selanjutnya, disarankan sebaiknya menambahkan variabel independen lain untuk mengetahui pengaruhnya terhadap kualitas audit, misalnya variabel biaya etika profesi, pengalaman kerja, tingkat pendidikan dan lain-lain yang diduga dapat mempengaruhi kualitas audit.

\section{REFERENSI}

Anwar Sanusi, 2017, Metode Penelitian Bisnis, Jakarta: Salemba Empat

Aprilia Whetyningtyas, 2014. Pengaruh Kompetensi, Independensi dan Profesionalisme Auditor Terhadap Kualitas Audit.Jurnal sosial dan budaya volume 7 No. 1 Juni 2014, 1-6

Arens, Alvin A, Randal J. Elder, Mark S. Beasley, 2014. Auditing dan Assurance Pendekatan Terintegrasi. Jakarta: Erlangga.

Arikunto, Suharsimi, 2010, Prosedur Penelitian : Suatu Pendekatan Praktek, Jakarta: Rineka Cipta.

David N. Herda dan Kasey A. Martin, 2016. The Effect of Auditor Experience and Prefessional Commitment on Acceptance of Underreveagfgdf adadgagporting Time: A Moderated Mediation Analysis. Current Issues in Auditing Vol.10, No. 2 Fall 2016 pp. A14A27 
Jurnal Akuntansi \& Perpajakan, Volume 1, No. 2, Januari 2020

Dwiwati Riandhini. Laporan

Keuangan Bermasalah, Inovasi Ganti Auditor. Melalui https://finance.detik.com/bursavalas/2924038/laporankeuangan-bermasalah-inovisiganti-auditor[25/05/15]

Eiteman, David K, Arthur I. Stonehill, Michael H. Moffet, 2013. Manajemen Keuangan Multinasional - Edisi Kesebelas. Jakarta: Erlangga.

Ghozali, Imam, 2011, Aplikasi Analisis Multivariate dengan Pendekatan Program IBM SPSS, Semarang: Badan Penerbit Universitas Diponegoro.

Ikatan Akuntan Indonesia, 2015. Standar Akuntansi Keuangan, Jakarta: Salemba Empat.

I Made Sudana, 2011. Manajemen Keuangan Perusahaan; Teori dan Praktek. Jakarta: Erlangga.

Institut Akuntan Publik Indonesia, 2011. SPAP, Standar Profesional AkuntanPublik. Jakarta : Salemba Empat

Keown, Arthur J, John D. Martin, J. William Petty, David F. Scott Jr, 2017. Manajemen Keuangan: Prinsip dan Penerapan, Edisi Kesepuluh, Jilid I. Penerbit: Indeks

Mochamad Ichrom, 2015. Pengaruh Kompetensi, Independensi dan Motivasi Auditor Terhadap Kualitas Audit. Jurnal Ilmu \& Riset Akuntansi Vo.4 No. 1 (2015).

Modesti, Claudius B. Ernest \& Young Indonesia Didenda di AS, Ini Tanggapan Indosat. Melalui https://bisnis.tempo.co/read/ne ws/2017/02/11 /087845617 lernst-young-indonesia- didenda-di-as-ini-tanggapanindosat\# zof5r6FtXafv V0R5.99 [11/02/17]

Mulyadi, 2013. Auditing. Jakarta: Salemba Empat

$\mathrm{Ni}$ Wayan, Ni Luh Gede \& Nyoman, T , 2014. Pengaruh Kompetensi, Independensi, dan Motivasi Terhadap Kualitas Audit.E-Jurnal S1 Akuntansi Universitas Pendidikan GaneshaVolume 2 No.1 2014.

Norma Kharismatuti, 2012. Pengaruh Kompetensi dan Independensi Terhadap Kualitas Audit Dengan Etika Auditor Sebagai Variabel Moderasi.Diponegoro Journal Of Accounting Volume 1 Nomor 1 Tahun 2012: 1-10

Porter, B.; Simon, J. and Hatherly, D, 2003. Principles of External Auditing, Second Edition, John Wiley \& Sons Ltd, England.

Putu Septiani Futri dan Gede Juliarsa, 2014. Pengaruh Independensi, Profesionalisme, Tingkat Pendidikan, Etika Profesi, Pengalaman dan Kepuasan Kerja Auditor pada Kualitas Audit Kantor Akuntan Publik di Bali. E-Jurnal Akuntansi Universitas Udayana Vol.7 No. 21 (2014).

Roger D. Martin, 2013. Audit Quality Indicators: Audit Practice Meets Audit Reserach. Current Issues in Auditing Volume 7, Issue 22013 Pages A17-A23

Sugiyono, 2013. Metode Penelitian Kuantitatif Kualitatif dan $R \& D$. Bandung: Alfabeta.

Sukrisno, Agoes, 2012. Auditing (Petunjuk Praktis Pemeriksaan Akuntan OlehAkuntan Publik). Jakarta : Salemba Empat 
Jurnal Akuntansi \& Perpajakan, Volume 1, No. 2, Januari 2020

Tarko Sunaryo, 2015. Black Market

Bisnis Akuntan. Iaiglobal.or.id, 22 September 2015

Theodorus M. Tuanakotta, 2014. Audit Kontemporer. Jakarta: Salemba Empat

Valery G. Kumaat (2011), Internal Audit. Penerbit:

Erlangga,Jakarta

Wibowo (2016),Manajemen

Kinerja. Penerbit: PT. Raja Grafindo Perkasa, Jakarta.

Yusar Sagara dan Fitri Yani Jalil, 2013. Auditing.Ciputat:UIN Jakarta Press. 